\title{
Comparative Study of Hematological and Biochemical Parameters during Different Phases of Menstrual Cycle in Young Healthy Women Aged 18-22 Years.
}

\author{
${ }^{1}$ Y. S. Usha Rani M. D ${ }^{2}$ P. Manjunath D. N. B ${ }^{3}$ K.N.Narasimhaswamy M. D. \\ 1 Assistant Professor, Department of Physiology, Adichunchanagiri Institute of Medical Sciences, Karnataka, \\ India. \\ 2 Consultant Physician, Department of General Medicine, Mysore Medical College \&Research Institute, \\ Mysore, Karnataka, India. \\ 3 Professor and Head, Department of Physiology, Adichunchanagiri Institute of Medical Sciences Karnataka, \\ India.
}

\begin{abstract}
Menstruation is a phenomenon unique to females and nearly universal experience in women's lives and is poorly understood. It is characterized by co-ordinated sequence of hormonal changes but the changes that occur in the distribution of hematological parameters and biochemical parameters have not been clearly established. The present study was undertaken with the following aim: $i$ ) To compare hematological parameters in different phases of menstrual cycle. ii) To compare biochemical parameters in different phases of menstrual cycle.
\end{abstract}

Materials \& Methods: The present study was carried out on healthy female medical students in the age group of 18 to 22 years with normal menstrual cycle of $30 \pm 3$ days. Various hematological and biochemical parameters were studied during different phases of menstrual cycle.

Result: RBC count and Hb were decreased in menstrual phase compared to other phases. Total leucocyte count was significantly $(p<0.001)$ increased in follicular phase and significantly decreased in luteal phase. Total platelet count was significantly $(p<0.001)$ increased during follicular phase compared to menstrual phase and Luteal phase. Erythrocyte sedimentation rate was significantly $(p<0.001)$ increased in menstrual phase compared to follicular phase. Differential leucocyte count revealed that all types of leucocytes showed hardly any variation during the different phases of menstrual cycle, except in case of eosinophil, which showed a significant $(p<0.01)$ decrease in follicular phase. Serum calcium levels were significantly higher in follicular phase than menstrual phase and luteal phase. Serum magnesium levels were significantly highest during luteal phase and lowest during the follicular phase. Serum sodium levels were significantly decreased in luteal phase compared to follicular phase and menstrual phase. Serum potassium levels did not show any significant changes in different phases of menstrual cycle.

Interpretation and Conclusion: This study was a moderate attempt to determine regular variation in the different hematological and biochemical parameters during the different phases of menstrual cycle in normal healthy females and evaluate conflicting reports on the subjects.

The cyclical changes in the electrolytes supports the claim of many women that they suffer changes in fluid and electrolyte balance in the premenstrual days.

Keywords: Menstrual cycle; Hematological parameters; Biochemical parameters;

\section{Introduction}

The menstrual cycle is a window into the general health and well-being of women, and not just a reproductive event. The hormonal changes occurring during menstrual cycle not only affect oocyte maturation and the endometrial and vaginal environment but can also have an effect on a number of other physiological \& biochemical phenomena ${ }^{29}$. It can indicate the status of bone health, heart disease, and ovarian failure, as well as long-term fertility. Apart from it being physiological there are various disorders associated with menstrual cycle which cause morbidity \& mortality.

The menstrual cycle is characterized by cyclical fluctuations in the levels of FSH, LH, estrogen and progesterone. These hormones are known to have an effect on oxygen carrying capacity, immune response, bleeding and also changes in serum electrolytes which may be responsible for variable physical, psychological symptoms and autonomic changes. It is suggested that stressful situations during ovulatory periods and menstruation may cause increased 17-hydroxy corticosterone levels with resulting eosinopenia ${ }^{6}$. Platelet function is periodically altered during the ovarian cycle due to the influence of progesterone and estrogen on Von Willebrand factor concentrations 9 
5-20\% of women reporting severe dysmenorrhea may be associated with reproductive morbidities like infection $^{40}$. Thus estimation of leucocyte count is an important tool. 9-14\% of reproductive-aged women have blood loss that exceeds $80 \mathrm{~mL}^{17}$ and prolonged and excessive bleeding may provoke or exacerbate anemia. Thus there arises a need to estimate Hemoglobin, Red Blood Cell count and ESR during the menstrual cycle.

Estrogen like aldosterone and some other adrenocortical hormones causes sodium and water retention by kidney tubules ${ }^{1}$. Whereas progesterone is a competitive inhibitor of aldosterone at the kidney, it has natriuretic action ${ }^{41}$. Certain autonomic changes have also been reported during these phases, though more so during the premenstrual phase. Estrogen has an effect on calcium homeostasis. Estrogen inhibits secretion of cytokines which foster the development of osteoclasts. It also stimulates production of transforming growth factor (TGF- $\beta$ ) which increases apoptosis of osteoclasts. Estrogen increases calcification of bone ${ }^{19}$.

\section{Material And Methods}

The present study was carried out on 30 healthy female medical students of Adichunchanagiri Institute of Medical Sciences, BG Nagara, Bellur in the age group of 18-22 years with the normal menstrual cycle of $30 \pm 3$ days. Cases of irregular periods, chronic disease and with history of drugs affecting the menstrual cycle were not included.

The purpose and methodology of the study were fully explained to all of them for their full cooperation and their relaxed mental condition was a prerequisite for appropriate results. The different parameters were done under the following phases of menstrual cycle:

Menstrual phase $\left(1^{\text {st }}\right.$ day to $5^{\text {th }}$ day of menstrual cycle $)$,

Follicular phase $\left(6^{\text {th }}\right.$ day to $14^{\text {th }}$ day of menstrual cycle) and

Luteal phase ( $15^{\text {th }}$ day to $28^{\text {th }}$ day of menstrual cycle)

Blood samples were drawn from anticubital vein $(3.5 \mathrm{ml})$ in a wax coated or plastic vial containing EDTA as anticoagulant. In order to avoid diurnal variation blood was collected in the morning time at 8:00 AM. The hematological investigations were performed using Hemo Auto analyzer-SYSMEX KX-21 in the department of Pathology, Adichunchanagiri Institute of Medical Sciences, BG Nagara, Bellur. ESR estimation was done by Westergren's method.

Each sample was analyzed for levels of serum calcium and magnesium on Selectra-E random access clinical chemistry analyzer and sodium and potassium on Medica's EasyLyte analyzers.

For Statistical analysis, Student's t-test was applied to determine the significance of values.

\section{Results}

30 female medical students were investigated during different phases of menstrual cycle namely Menstrual phase (MP), Follicular phase (FP), Luteal phase (LP).

Table: 1Hematological parameters during different phases of menstrual cycle.

\begin{tabular}{|c|c|c|c|}
\hline Parameter & $\begin{array}{l}\text { Menstrual phase } \\
\text { (Mean } \pm \text { SD) }\end{array}$ & $\begin{array}{l}\text { Follicular phase } \\
(\text { Mean } \pm \text { SD) }\end{array}$ & $\begin{array}{l}\text { Luteal phase } \\
\text { (Mean } \pm \text { SD) }\end{array}$ \\
\hline $\begin{array}{lll}\text { Red blood } & \text { cell } & \text { count } \\
(\text { cells/cumm) }\end{array}$ & $4.34 \pm 0.37$ & $4.37 \pm 0.45$ & $4.44 \pm 0.47$ \\
\hline Hemoglobin $(\mathrm{g} / \mathrm{dl})$ & $11.47 \pm 1.29$ & $12.01 \pm 1.15$ & $12.06 \pm 1.21$ \\
\hline $\begin{array}{lll}\text { Total leucocyte count } \\
\text { (cells/cumm) }\end{array}$ & $5953.33 \pm 1.35$ & $6675 \pm 1.11$ & $5740 \pm 1$ \\
\hline $\begin{array}{l}\text { Total eosinophil count } \\
\text { (cells/cumm) }\end{array}$ & $159.17 \pm 61.75$ & $123.33 \pm 62.60$ & $150 \pm 80.14$ \\
\hline $\begin{array}{ll}\begin{array}{l}\text { Total platelet count } \\
\text { (cells/cumm) }\end{array} & \\
\end{array}$ & $2.31 \pm 0.63$ & $3.09 \pm 0.64$ & $2.35 \pm 0.49$ \\
\hline $\begin{array}{l}\text { Erythrocyte sedimentation rate } \\
(\mathrm{mm} / \mathrm{hr})\end{array}$ & $23.83 \pm 11.57$ & $15.67 \pm 9.71$ & $18.50 \pm 11.31$ \\
\hline
\end{tabular}

significantly increased

- $\quad \mathrm{RBC}$ count and $\mathrm{Hb}$ were decreased in menstrual phase compared to other phases but significant values were not noted when compared during different phases of menstrual cycle.

- Total leucocyte count was significantly $(\mathrm{p}<0.001)$ increased in follicular phase and significantly decreased in luteal phase.

- Total platelet count was significantly $(\mathrm{p}<0.001)$ increased during follicular phase compared to menstrual phase and Luteal phase. 
- Erythrocyte sedimentation rate was significantly $(\mathrm{p}<0.001)$ increased in menstrual phase compared to follicular phase.

Table :2 Differential leucocyte count during different phases of menstrual cycle.

\begin{tabular}{|l|l|l|l|}
\hline Parameter & $\begin{array}{l}\text { Menstrual phase } \\
(\text { Mean } \pm \text { SD) }\end{array}$ & $\begin{array}{l}\text { Follicular phase } \\
(\text { Mean } \pm \text { SD) }\end{array}$ & $\begin{array}{l}\text { Luteal phase } \\
(\text { Mean } \pm \text { SD) }\end{array}$ \\
\hline Neutrophils (\%) & $58.63 \pm 8.39$ & $59.17 \pm 6.7$ & $57.57 \pm 8.31$ \\
\hline Lymphocytes (\%) & $33.7 \pm 7.81$ & $33.97 \pm 6.6$ & $35.6 \pm 7.77$ \\
\hline Eosinophils (\%) & $2.63 \pm 1.06$ & $1.93 \pm 0.98$ & $2.43 \pm 1.43$ \\
\hline Monocytes (\%) & $4.73 \pm 1.46$ & $5.2 \pm 1.12$ & $4.3 \pm 1.31$ \\
\hline Basophils (\%) & $0.3 \pm 0.46$ & $0.17 \pm 0.37$ & $0.17 \pm 0.37$ \\
\hline
\end{tabular}

- Differential leucocyte count revealed that all types of leucocytes showed hardly any variation during the different phases of menstrual cycle, except in case of eosinophil, which showed a significant $(\mathrm{p}<0.01)$ decrease in follicular phase.

Table : 3 Serum electrolyte levels during different phases of menstrual cycle.

\begin{tabular}{|c|c|c|c|}
\hline Parameters & $\begin{array}{l}\text { Menstrual phase } \\
(\text { Mean } \pm \text { SD) }\end{array}$ & $\begin{array}{l}\text { Follicular phase } \\
(\text { Mean } \pm \text { SD) }\end{array}$ & $\begin{array}{l}\text { Luteal phase } \\
(\text { Mean } \pm \text { SD) }\end{array}$ \\
\hline Calcium (mg/dl) & $9.50 \pm 0.43$ & $9.74 \pm 0.43^{\text {*w/ }}$ & $9.28 \pm 0.41$ \\
\hline Magnesium (mg/dl) & $2.156 \pm 0.25$ & $1.984 \pm 0.30^{\circ}$ & $2.41 \pm 0.30^{\text {佽 }}$ \\
\hline Sodium $(\mathrm{mmol} / \mathrm{l})$ & $142.51 \pm 2.03$ & $141.108 \pm 1.74$ & $140.02 \pm 2.12^{\text {冰 }}$ \\
\hline Potassium $(\mathrm{mmol} / \mathrm{l}) \bullet$ & $4.13 \pm 0.31$ & $4.20 \pm 0.42$ & $4.28 \pm 0.43$ \\
\hline
\end{tabular}

* significantly higher as compared to the other two $(\mathrm{p}<0.001)$

* significantly lower as compared to the other two $(\mathrm{p}<0.01)$

* significantly lower as compared to the other two $(\mathrm{p}<0.01)$

-Potassium values were not significant.

- Serum calcium levels were significantly higher in follicular phase than menstrual phase and luteal phase.

- Serum magnesium levels were significantly highest during luteal phase and lowest during the follicular phase.

- Serum sodium levels were significantly decreased in luteal phase compared to follicular phase and menstrual phase.

- Serum potassium levels did not show any significant changes in different phases of menstrual cycle.

\section{Discussion}

In the present study, Hemoglobin and Red Blood Cell Count increased from menstrual Phase (MP) to luteal Phase (LP) but were not statistically significant. Hemoglobin concentration increased from menstrual phase to luteal phase due to increased erythropoiesis to compensate for the blood loss during menses. Progesterone has a natriuretic effect attributed to aldosterone antagonism, which results in plasma loss of sodium and water and hemoconcentration ${ }^{28}$. Some studies showed that hemoglobin concentrations were significantly lower in follicular phase than in the luteal phase ${ }^{42,21,2,10}$. In the present study, erythrocyte sedimentation rate $(\mathrm{mm} / \mathrm{hr})$ was significantly increased in MP compared to FP $(\mathrm{P}<0.01)$.

Several studies ${ }^{7,22}$ are in general agreement with the fact that the leucocyte count increased during the follicular phase and decreased during luteal phase. Although some ${ }^{23,30}$ exhibit a mild increase in total leucocyte count around follicular, yet no significant changes were observed.

The changes in the circulating leucocyte count during the menstrual cycle is associated with the presumptive changes in blood estrogen and the possibility that they are influenced by blood gonadotrophic hormone at the time of ovulation, or by blood progesterone or body temperature during the latter half of the cycle, cannot be excluded. These observations are in contrary to some studies ${ }^{24,31}$ in which they did not find any change in the number of circulating leucocytes in relation to the menstrual cycle.

In the present study differential leucocyte count revealed that all types of leucocytes showed hardly any variation during the different phases of menstrual cycle, except in case of eosinophil, which showed a significant decrease around follicular phase. Similarly basophil showed decreased count around follicular and luteal phase versus the menstrual phase. These midcycle and premenstrual falls are probably due to migration of the cells from the peripheral blood into the rupturing follicle of the ovary and into the ischemic premenstrual endometrium $^{35}$. The eosinophil count significantly $(\mathrm{p}<0.05)$ drops at mid-cycle and then its level increases during luteal phase are in agreement with the observations made by several authors ${ }^{25}$. According to them eosinopenia during mid-cycle (14th day) is a result of physiologic stress and one might expect a simultaneous increase in levels of steroid hormones in blood ${ }^{32,33}$. A mid-cycle peak elevation in platelet count, which followed by a gradual decline may be due to leuteal hormone which inhibit the spleen from releasing platelets ${ }^{14,15}$. 
In the present study serum calcium levels were significantly higher in follicular phase than menstrual and luteal phases. Earlier research showed that the increase in serum calcium levels during the follicular and luteal phases could be due to the effect of estrogen on the parathyroid glands. The estrogen causes increase in parathyroid activity which leads to marked acceleration of calcium uptake ${ }^{36}$. Serum calcium in the present study was found to be lowest during luteal phase inspite of an increase in estrogen level. This relationship cannot be explained on the basis of estrogen levels and parathyroid activity alone. The higher levels of progesterone than estrogen during luteal phase could be responsible for low serum calcium levels ${ }^{4}$.

The levels of serum magnesium in present study were significantly highest during the luteal phase and lowest during the follicular phase. The raised estrogen levels possibly by acting through parathyroid hormone could be responsible for depicting the body stores of magnesium by decreasing the reabsorption of magnesium ions by the renal tubules thus resulting in midcycle decline ${ }^{5}$. Therefore, it is suggested that calcium/magnesium ratio may be related to the premenstrual syndrome complaints that some women have during this period ${ }^{34}$.

Our findings of serum sodium and potassium levels during menstrual cycle correlated well with the findings of M. Mira et $\mathrm{al}^{26}$. Although, it is documented that during the luteal phase of the menstrual cycle sodium-retaining hormone secretion increase ${ }^{6}$, present study found a significant decrease in sodium in luteal phase. Possible causes for this change in sodium concentration include the increased concentrations of antidiuretic hormone in the luteal phase ${ }^{27}$ and the antagonism effect of progesterone to the typical sodium retentive influence of aldosterone ${ }^{37}$.

\section{Conclusion}

With respect to hematological parameters, hormonal changes and nutrition play a major role. In the present study we found decreased RBC count which increases rouleaux formation thus increasing ESR in the menstrual phase. The cyclical changes in the electrolytes supports the claim of many women that they suffer changes in fluid and electrolyte balance in the premenstrual days. Moreover, these changes may have significance in terms of the normal reference interval, hence necessitate small but significant alterations to the normal reference interval for calcium, magnesium and sodium in menstruating women.

\section{References}

[1]. Arthur.C Guyton, John.Hall. Text book of medical physiology, Edn 12, Elsevier publications.2008;1018.

[2]. Am J Ther, Apseloff G, Bao X, LaBoy-Goral L, Friedman H, Shah A. Practical considerations regarding the influence of the menstrual cycle on leukocyte parameters in clinical trials. $2000 \mathrm{Sep} ; 7(5): 297-302$

[3]. A.K.Jain,Manual of practical physiology. 4th edn. Arya publications; 2012:50-53

[4]. K. Pandya, S. Chandwani, T. K. Das et al. Serum calcium, magnesium and inorganic phosphorus levels during various phases of menstrual cycle. Indian J Physiol Pharmacol. 1995;39:411-4.

[5]. Zittermann, I. Schwarz, K. Scheld, et al. Physiologic fluctuations of serum estradiol levels influence biochemical markers of bone resorption in young women. J Clin Endocrinol Metab. 2000;85(1):95-101.

[6]. M. Michelakis, H. Yoshida, J. C. Dormois. Plasma renin activity and plasma aldosterone during the normal menstrual cycle. Am J Obstet Gynecol. 1975;123:724-6

[7]. Bain BJ, England JM. Variations in leucocyte count during menstrual cycle. Br Med J 1975;2:473-5.

[8]. D.V.B.Dapper \& B.C.Didia.Haemorrheological changes during the menstrual cycle,East African Medical Journal vol. 2002;79(4) :181-183.

[9]. Guyton AC. Textbook of Medical Physiology. Eighth edition. W.B.Saunders Philadelphia; 1991

[10]. Gupta R, Mehrotra HN, Negi VK, Pant MC, Mishra. Studies on total platelets, leucocytes and eosinophils during and around ovulatory period in Indian girls. Indian Med Gazette

[11]. $1977 ; 17(5): 159$

[12]. Gupta R, Negi VK, Pant MC, Mehrotra HN. A study of midcyclic variations in platelets, eosinophils, leucocytes andserum Ca and P with a view to anticipate ovulation. Ind $\mathrm{J}$

[13]. Physiol Pharmacol 1980;24(5):440.

[14]. Hallberg L, Hogdahl AM, Nilsson L, Rybo G. Menstrual blood loss-a population study. Variation at different ages and attempts to define normality. Acta Obstet Gynecol Scand. 1966;45:320-351.

[15]. Kim. Barret,Susan. Barman,Scott. Boitano,Heddwen.Brooks. Ganong's Review of Medical Physiology,Edn 24,Tata McGraw-Hill publishers; 2012;389-401.

[16]. Loraine IA, Bell ET. Hormone excretion during the normal menstrual cycle. Lancet. 1963;1:1340-2

[17]. MacKinnon IL. Observation on total leucocyte counts during thirteen consecutive human menstrual cycles. J Obstet Gyanecol 1953;60:721-6.

[18]. Mettler L, Shirwani D. The blood count during the ovarian cycle. Am J Obstet Gyanecol 1974;119:1038-43.

[19]. Makinoda S, Mikuni M, Sogame M, Kobamastsu Y, Yamada H, Yamamoto R, Fujimoto S, Furuta I. Erythropoietin, granulocytecolony stimulating factor, interlukin-1 beta and interlukin-6 during the menstrual cycle. Int J Gyanecol Obstet 1996;55:265-71.

[20]. Mehrotra HN, Pant MC, Tandon GK, Negi VK. A Study of certain haematological and metabolic changes during preovulatory period. Indian J Physiol Pharmacol 1978;22(2):188.

[21]. M. Mira, P. M. Stewart, V. Gebski, et al. Changes in sodium and uric acid concentrations in plasma during the menstrual cycle. Clin Chem 1984 Mar;30(3):380-1

[22]. M. L. Forsling, M. Akerlund, P. Stromberg. Variations in plasma concentrations of vasopresain during the menstrual cycle. J Endocrinol. 1981;89,263-266.

[23]. Odd D Vellar.Changes in Hemoglobin Concentration and Hematocrit During the Menstrual Cycle: A Cross-sectional Study. Acta Obstet Gynecol Scand, Acta Obstetricia et GynecologicaScandinavica.1974;53 (3), 243-246. 
[24]. P. Dullo, N. Vedi. Changes in serum calcium, magnesium and inorganic phosphorus levels during different phases of the menstrual cycle. J Hum Reprod Sci. 2008; 1(2):77-80.

[25]. Pathak NR, Desai CA, Chandwani S. Hematological changes during normal menstrual cycle. Indian J Physiol Pharmacol1981;25(4):440

[26]. Pohle FJ. The blood platelet count in relation to the menstrual cycle in normal Women. Am J Med Sci 1939; $197: 40-47$.

[27]. Pepper H, Lindsay S. Levels of platelets, eosinophils, total leucocytes and polymorphonuclear leucocytes during the normal menstrual cycle. J Am Coll Obstet Gyanecol 1959;14:657.

[28]. Pepper H, Lindsay S. Levels of eosinophils, platelets, leucocytes and 17-hydroxycorticosteroids during the normal menstrual cycle. Proc Soc Exp Biol Med 1960;104:145-7.

[29]. P. Dullo, N. Vedi. Changes in serum calcium, magnesium and inorganic phosphorus levels during different phases of the menstrual cycle. J Hum Reprod Sci. 2008;1(2):77-80.

[30]. Rajan P, Rao GS, Walter S. Blood basopenia as indicator of ovulation. Indian J Physiol Pharmacol 1992;36(2):115-7.

[31]. R. M. Pitkin, W. A. Renolds, G. A. William, et al. Calcium regulating hormones during the menstrual cycle. J Clin Endocrinol Metabol. 1978;47(3):626-32.

[32]. R. L. Landau, K. Lugibihl. Inhibition of the sodium-retaining influence of aldosterone by progesterone. J Clin Endocrinol Metab.1958;18:1237-1245

[33]. Sioba'n D. Harlow, Oona M.R. Campbell. Epidemiology of menstrual disorders in developing countries:a systematic review, BJOG: an International Journal of Obstetrics and Gynaecology. January 2004; Vol. 111, pp. 6-16

[34]. Susan P. Endocrine physiology, copyright 1997, mosby publishers; 1997:182.

[35]. Simmons, Butterworth Heinemann uk. Microcytic Hypochromic Anemias in Hematology: A Combined Theoretical and Technical Approach. 1997; $2^{\text {nd }}$ Edn,pp: 53-58. 